(C) 2021, The Authors. Published by Elsevier Inc. and Fass Inc. on behalf of the American Dairy Science Association ${ }^{\circledR}$.

This is an open access article under the CC BY-NC-ND license (http://creativecommons.org/licenses/by-nc-nd/4.0/).

\title{
Positive genetic merit for fertility traits is associated with superior reproductive performance in pasture-based dairy cows with seasonal calving
}

\author{
S. Meier, ${ }^{1 *} \odot$ B. Kuhn-Sherlock, ${ }^{1} \odot$ P. A. Amer, ${ }^{2} \odot$ J. R. Roche,,${ }^{1} \dagger \odot$ and C. R. Burke ${ }^{1} \odot$ \\ 'DairyNZ Limited, Private Bag 3221, Hamilton 3240, New Zealand \\ ${ }^{2}$ AbacusBio Limited, 442 Moray Place, Dunedin 9016, New Zealand
}

\begin{abstract}
New Zealand's Fertility Breeding Value (FertBV) is reported as the percentage of a sire's daughters that calve in the first $42 \mathrm{~d}$ of the seasonal calving period and is an estimate of genetic merit for fertility for dairy cattle. Reproductive physiology, milk production, and changes in body weight and body condition score of 2 groups of cows divergent in FertBV $(+5.0 \%$ : POS; $-5.1 \%$ : NEG) were characterized during their first 2 lactations. Cows grazed fresh pasture and were managed in a seasonal calving system; they were bred by artificial insemination on observed estrus for the entire breeding period (98 d in lactation 1 and $76 \mathrm{~d}$ in lactation 2). During lactation 1, all animals were primiparous and were randomly allocated to 1 of 2 herds, ensuring each herd was balanced for FertBV and expected calving date. During lactation 2, cows that became pregnant during lactation 1 were managed as 1 herd. Cows not inseminated in the first $42 \mathrm{~d}$ of the breeding season were examined for the presence of a corpus luteum and treated with an anestrus program. On average, the interval from calving to ovulation was $19 \mathrm{~d}$ longer in lactation 1 and $10 \mathrm{~d}$ longer in lactation 2 for NEG FertBV cows. The percent of cows submitted for artificial insemination after 21 d (i.e., submission rate) was 38 and 25 percentage points greater in the POS FertBV cows during lactations 1 and 2, respectively. Pregnancy rate from $42 \mathrm{~d}$ of breeding was 33 and 30 percentage points greater, respectively. There was no effect of FertBV on vaginal discharge score postcalving; however, POS FertBV cows had a 50\% lower risk of having subclinical endometritis (polymorphonuclear leukocytes $>7 \%$ ) $42 \mathrm{~d}$ postcalving. Interactions between FertBV and month relative to calving identified that NEG FertBV cows were fatter (greater body condition
\end{abstract}

Received January 20, 2021.

Accepted May 12, 2021.

*Corresponding author: Susanne.Meier@dairynz.co.nz

$\dagger$ Current affiliation: School of Biological Sciences, The University of Auckland, Symonds St, Auckland 1142, New Zealand. score) in the month before calving, but thinner between 3 and 5 mo postcalving. There was no effect of FertBV on lactation length, estimated 270-d milk yields, or daily milk, fat, or protein yields, and only small effects on milk fat and protein percentage across the lactations. In summary, the POS FertBV cows had superior uterine health, a shorter calving to ovulation interval, a greater submission rate, and a greater pregnancy rate earlier in the breeding season when compared with the NEG FertBV cohort. Based on these results, these may be useful phenotypes to include in genetic selection indices.

Key words: submission, pregnancy, lactation, genetic fertility

\section{INTRODUCTION}

A global decline in the phenotypic and genetic fertility of lactating dairy cows was evident 20 yr ago (Berry et al., 2014b; Pryce et al., 2014), with 40 to $64 \%$ of the phenotypic decline in fertility in dairy cattle in the United States and Ireland attributable to genetics (VanRaden et al., 2004; Berry et al., 2014a). The international response to this was an increased emphasis on health and fertility traits in breeding objectives in many countries (Miglior, 2002; Miglior et al., 2005; Harris et al., 2006; Egger-Danner et al., 2015). For example, in 2003, health and fertility traits were estimated at $13 \%$ of the total selection index in an analysis of 15 countries; health and reproduction constituted $36 \%$ of the breeding index in 17 countries in an analysis of 2010 to 2013 data (this included many of the original 15 countries), with fertility alone at 16\% (Miglior et al., 2005; Cole and VanRaden, 2018).

Increased emphasis on fertility traits in genetic selection objectives has contributed to improved reproductive performance on-farm (Berry et al., 2014b; Pryce et al., 2014). However, achieving these on-farm gains is challenged by the low heritability of the chosen fertility traits, the value proposition of selecting for fertility compared with more highly heritable milk traits, and the interaction between genetics and the management 
environment (Berry et al., 2014a; Cole and VanRaden, 2018; Craig et al., 2018; Dennis et al., 2018). Nevertheless, despite these challenges, small year-on-year gains in genetic fertility are evident where national selection objectives include fertility traits (Pryce et al., 2014).

The Fertility Breeding Value (FertBV) describes the fertility traits used in New Zealand (Harris et al., 2006). The inclusion of this trait in the national breeding objectives, however, has only resulted in an estimated $0.1 \%$ gain in FertBV per year at an industry level for the $10 \mathrm{yr}$ between 2005 and 2015 (DairyNZ, 2017b). However, the rate of genetic gain could be accelerated if new traits that are more highly correlated with desired reproductive outcomes or traits with greater heritability and ease and accuracy of measurement are included in the quantification of the FertBV.

The objective of this experiment was to determine some of the underlying physiological and immunological differences between cows differing in their genetic merit for fertility by measuring the interval duration from calving to first recorded ovulation, percent of cows submitted for AI during the first 3 wk of breeding, uterine recovery and inflammation scores, and pregnancy and recalving rates. Milk production and changes in BCS and BW are also reported. Understanding the key processes underpinning reproductive failure could provide targets for development of easy-to-measure phenotypes correlated with desired reproductive outcomes.

\section{MATERIALS AND METHODS}

\section{Fertility Breeding Value and Animal Management}

This experiment was undertaken at the Tokanui Research Farm (Waikato), New Zealand $\left(38^{\circ} 08^{\prime}\right.$ S, $175^{\circ} 33^{\prime}$ E, $40 \mathrm{~m}$ above sea level). The Ruakura Animal Ethics Committee approved the animal measurements undertaken in this experiment (AE application \#14200).

The evaluation of genetic merit for fertility included 6 binomial reproductive traits (breeding within $21 \mathrm{~d}$ of the planned start of seasonal breeding in lactations 1 , 2 , and 3 and recalving in the first $42 \mathrm{~d}$ of the seasonal calving period in lactations 2,3 , and 4 ) and 2 predictor traits (milk volume and BCS in the cow's first lactation at 60 DIM; DairyNZ, 2018).

A full description of the establishment of the research herd representing cows divergent in FertBV $(+5.0 \%$ : POS; -5.1\%: NEG) is available elsewhere (Meier et al., 2021). Briefly, experimental herd size was determined based on a power analysis that considered a trait heritability as 0.05 for pregnancy rate after $42 \mathrm{~d}$ of breeding, and where a difference of $14 \%$ pregnancy rate after $42 \mathrm{~d}$ of breeding may be expected based on a $10 \%$ difference between the POS and NEG FertBV lines (200 cows in each line, with $80 \%$ confidence and a $5 \%$ significance level). A breeding plan to produce heifer calves with a 10-percentage point difference in FertBV (POS and NEG) was devised using MateSel (Kinghorn, 2011). The expected parent averages for EBV for milk volume, fat yield, protein yield, BW (DairyNZ, 2018), and ancestry (percent North American Holstein-Friesian; HF) were restricted to within 1 standard deviation of each other. Calves were at least fifteen-sixteenths $\mathrm{HF}$, and the inbreeding coefficient was $2.8 \pm 1.44 \%$ (mean $\pm \mathrm{SD}$, target $<6.3 \%$ ). Table 1 summarizes the total merit index (Breeding Worth), FertBV, and individual breeding values for heifers with POS and NEG FertBV, as well as the Breeding Worth and FertBV of their dams and sires. To put the FertBV of the POS and NEG FertBV groups into context, the average FertBV is 0.2 with a standard deviation of 2.0 for all heifers born in $2015(\mathrm{n}=634,943)$.

Calves were collected from 379 herds across the North Island of New Zealand. From collection, calves were reared for 13 wk until weaning. Postweaning, heifers were transferred to a grazing property and managed in 1 of 4 groups in one location, with the POS and NEG FertBV heifers equally represented in all groups. Heifers were bred at approximately 14 mo of age for 98 d. Heifers were bred to 15-mo-old Jersey bulls, which were comingled with the heifers at a ratio of 1 bull per 20 heifers. Pregnant heifers were transferred to the milking farm at approximately 21 mo of age. The 513 heifers expected to calve (POS FertBV, $\mathrm{n}=271$; NEG FertBV, $n=242$ ) were randomly allocated to 1 of 2 herds for lactation 1, ensuring each herd was balanced for expected calving date and FertBV. For lactation 2, 338 cows (POS FertBV, $\mathrm{n}=211$; NEG FertBV, $\mathrm{n}=$ 126) were managed as 1 herd.

Cows were rotationally grazed as described by Roche et al. (2007). Cows had access to a fresh allocation of pasture twice daily (after each milking) and only returned to the same area when a minimum of 2 leaves had appeared on the majority $(>66 \%)$ of the perennial ryegrass (Lolium perenne L.) tillers (pregrazing herbage masses were $2,500-3,000 \mathrm{~kg}$ of $\mathrm{DM} / \mathrm{ha}$ in spring, $4,000-4,100 \mathrm{~kg}$ of $\mathrm{DM} / \mathrm{ha}$ in summer, and 3,000-3,200 $\mathrm{kg}$ of $\mathrm{DM} / \mathrm{ha}$ in autumn and winter; all measurements to ground level).

\section{Milk Yield, Milk Composition, and SCC}

Four herd tests were undertaken in lactation 1 (October, December, February, April) and 7 herd tests were undertaken in lactation 2 (August, September, October, November, December, February, April); all analyses were undertaken by LIC Milk Labs (LIC, Hamilton, New Zealand) using a Fossomatic FT120 (Foss Electric; 
LIC, 2019b). For each lactation, herd test data were grouped into DIM categories as follows: 0 to 30,31 to 60, 61 to 90,91 to 120,121 to 150,151 to 180,181 to 210, 211 to 240 , and 241 to 270 DIM. Estimated 270-d milk, fat, and protein yields were calculated using the test interval method (ICAR, 2019).

All analyses were undertaken using SAS/STAT 14.3 (SAS Institute Inc.). Significances were declared if $P \leq$ 0.05. Monthly milk production, composition, and SCC data were analyzed from mo 1 to 9 of lactation. Data were analyzed using repeated measures ANOVA and mixed models (PROC MIXED), with EBV generated before the cows' own records were included (i.e., Febru- ary 2017; volume, fat, protein, somatic cell), calving season day (CSD; expressed as the number of days from June 1 of each respective year), and difference between date of herd test and month midpoint as covariates. Random effects were sire and cow, and fixed effects were FertBV (POS, NEG), month (1-9), and their interactions. An autoregressive [type $=\operatorname{ar}(1)]$ covariance pattern was used. Estimated 270-d milk, fat, and protein yields were analyzed using analysis of covariance (ANCOVA, PROC MIXED), with EBV (volume, fat, protein) and CSD as covariates. The model included FertBV (POS, NEG) as a fixed effect, and sire as a random effect.

Table 1. Mean of component traits and estimated genetic merit of the heifers with positive (POS) or negative (NEG) genetic merit for fertility traits that were available for the study

\begin{tabular}{|c|c|c|c|c|}
\hline \multirow[b]{3}{*}{ Item } & \multicolumn{4}{|c|}{ Genetic merit for fertility traits } \\
\hline & \multicolumn{2}{|c|}{ POS } & \multicolumn{2}{|c|}{ NEG } \\
\hline & Mean & $\mathrm{SD}$ & Mean & $\mathrm{SD}$ \\
\hline Heifers (n) & 275 & - & 249 & - \\
\hline Date of birth $(\mathrm{d} / \mathrm{mo} ; \mathrm{d})$ & $3 \mathrm{Aug}$ & 14 & $7 \mathrm{Aug}$ & 15 \\
\hline \multicolumn{5}{|l|}{ Estimated genetic merit $^{1}$} \\
\hline $\operatorname{FertBV}^{2}(\%)$ & 5.0 & 0.74 & -5.1 & 1.36 \\
\hline Breeding Worth ${ }^{3}(\mathrm{NZ} \$ / \mathrm{yr})$ & 109 & 21.4 & 40 & 30.7 \\
\hline Volume $\mathrm{BV}^{4}(\mathrm{~kg})$ & 654 & 165.1 & 732 & 157.6 \\
\hline Fat $\mathrm{BV}^{4}(\mathrm{~kg})$ & 11.3 & 5.46 & 17.8 & 6.57 \\
\hline Protein $\mathrm{BV}^{4}(\mathrm{~kg})$ & 17.8 & 6.57 & 23.2 & 4.57 \\
\hline Body weight $\mathrm{BV}^{4}(\mathrm{~kg})$ & 37 & 12.5 & 40 & 10.1 \\
\hline $\mathrm{BCS} \mathrm{BV}^{5}$ & 0.07 & 0.068 & -0.08 & 0.071 \\
\hline Gestation length BV (d) & -3.2 & 2.07 & -1.4 & 2.23 \\
\hline Residual survival BV & 54 & 58.1 & 30 & 72.7 \\
\hline Total longevity BV (d of life) & 300 & 47.6 & 74 & 82.4 \\
\hline $\mathrm{SCS} \mathrm{BV}^{6}$ & -0.11 & 0.140 & 0.10 & 0.175 \\
\hline Ancestry $^{7}$ (North American \%) & 56 & 6.3 & 62 & 8.4 \\
\hline $\operatorname{Dams}^{8}(\mathrm{n})$ & 273 & - & 246 & - \\
\hline $\operatorname{FertBV}^{2}(\%)$ & 4.6 & 1.00 & -3.60 & 1.62 \\
\hline Breeding Worth ${ }^{3}(\mathrm{NZ} \$ / \mathrm{yr})$ & 89 & 28.7 & 39 & 29.9 \\
\hline $\operatorname{Sires}^{9}(\mathrm{n})$ & 24 & - & 43 & - \\
\hline FertBV $^{2}(\%)$ & 5.1 & 1.67 & -6.10 & 2.33 \\
\hline Breeding Worth $^{3}(\mathrm{NZ} \$ / \mathrm{yr})$ & 132 & 34.8 & 35 & 46.3 \\
\hline
\end{tabular}

${ }^{1}$ New Zealand Animal Evaluation Limited run date: January 2017.

${ }^{2}$ Fertility BV (FertBV) is calculated from 8 predictor traits with the 6 fertility traits submitted for breeding in the first $21 \mathrm{~d}$ of the breeding season in lactations 1,2 , and 3 , and calving in the first $42 \mathrm{~d}$ of calving in lactation 2,3 , and 4 , and milk yield and BCS in lactation 1 (DairyNZ, 2017a).

${ }^{3}$ Breeding Worth $(\mathrm{NZ} \$ / \mathrm{yr})$ is the NZ\$ net farm income per $5 \mathrm{t}$ of $\mathrm{DM}$, which is assumed to be fed per cow per year as calculated using economic weightings applied in 2016. The majority of the difference observed between lines can be attributed to the difference in the FertBV, which had an economic weighting of $\$ 6.84$ in 2016 . The US\$ equivalent for POS BW $=\$ 78(\mathrm{NZ} \$ 109)$; the US\$ equivalent for NEG BW $=\$ 29(\mathrm{NZ} \$ 40)$

${ }^{4}$ The breeding plan aimed to reduce the variation in the breeding value (BV) for milk volume, fat, protein, BW, and ancestry (\% North American Holstein-Friesian) to be within 1 SD and produce calves of more than fifteen-sixteenths Holstein-Friesian breeding.

${ }^{5}$ Body condition score is a measure of subcutaneous fat deposits (Roche et al., 2004), calculated using records collected on primiparous 2-yr-old heifers. These records are collected in early lactation. Raw scores are converted into a d 60 lactation equivalent, and then entered in the Animal Evaluation model. A "breed neutral" adjustment has been applied to this BV, such that the breed average for this trait is 0 across all breeds.

${ }^{6} \mathrm{SCS}$ is the log-transformed SCC, which is derived from milk testing (DairyNZ, 2017a).

${ }^{7}$ Ancestry data were based on information received from New Zealand Animal Evaluation Limited following parentage checks (February, 2016).

${ }^{8}$ Twin heifer calves were collected from 5 dams.

${ }^{9}$ Parentage verified sires of the calves. 


\section{The BW and BCS}

Cows were weighed (Gallagher New Zealand) and BCS was assessed (10-point scale, where 1 is emaciated and 10 is obese; Macdonald and Roche, 2004; Roche et al., 2004) as soon as practical after parturition. During lactation 1, BW and BCS were determined every $2 \mathrm{wk}$ following the a.m. milking or at approximately 0900 $\mathrm{h}$ during the nonlactating period. During the second lactation, BW and BCS were determined monthly at a similar time of day. The BW and BCS were grouped into 13 categories: precalving $(\mathrm{mo}-3=-91$ to $-61 \mathrm{~d}$, mo $-2=-60$ to $-31 \mathrm{~d}$, and mo $-1=-30$ to $-1 \mathrm{~d}$ ), calving (mo 0,0 to $6 \mathrm{~d}$ postcalving), and postcalving (mo 1 to 10; represented as 7 to $30 \mathrm{~d}, 31$ to $60 \mathrm{~d}, 61$ to $90 \mathrm{~d}, 91$ to $120 \mathrm{~d}, 121$ to $150 \mathrm{~d}, 151$ to $180 \mathrm{~d}, 181$ to $210 \mathrm{~d}, 211$ to $240 \mathrm{~d}, 241$ to $270 \mathrm{~d}$, and 271 to $300 \mathrm{~d}$, respectively).

Data were analyzed with a mixed model ANOVA (PROC MIXED), using an autoregressive [type = $\operatorname{ar}(1)]$ covariance pattern. The model included CSD, BCS EBV, or BW EBV as covariates; FertBV (POS, NEG), month, and their interaction as fixed effects; and sire and cow as random effects.

\section{Breeding Management}

The routine mating-management policy for the farm was to submit cows for AI based on estrus detection by visual observation with the aid of paint applied to the tail-head (Macmillan et al., 1988). The seasonal breeding periods for lactations 1 and 2 were 98 and 76 d, respectively.

During both breeding periods, cows were bred to AI through the entire seasonal breeding period, except for those cows transiently separated from the main herds into the "sick group," where they were comingled with a Hereford bull. During the first lactation breeding period, POS and NEG FertBV cows were randomly assigned to an AI sire with POS or NEG FertBV, respectively, for the first $63 \mathrm{~d}$, followed by a further $21 \mathrm{~d}$ of AI with semen from bulls categorized for short gestation length (LIC, 2019a). During the second lactation breeding season, all cows were inseminated using commercially available sires selected by the farm manager.

For both lactations, cows not mated in the first 42 $\mathrm{d}$ were examined for the presence of a corpus luteum using transrectal ultrasonography with a 5 to $15 \mathrm{MHz}$ probe (SonoScape S6V, Euromed Medical Systems). Cows were examined approximately $44 \mathrm{~d}$ after the start of breeding. Those cows without a corpus luteum were treated with an intravaginal $\mathrm{P} 4$-releasing device (CIDR; Zoetis New Zealand Ltd) from d -9 to -2 relative to timed AI, gonadorelin (Ovurelin $100 \mathrm{mg}$ i.m.;
Bomac Laboratories Ltd.) on d -9 relative to timed AI, and $500 \mathrm{mg}$ of cloprostenol i.m. on d -2 (Ovuprost, Bayer New Zealand Limited). Cows were bred using timed AI (d 0) and subsequently on observed estrus.

\section{Pregnancy Diagnoses}

For both lactations, fetal-aged pregnancy diagnosis was undertaken to enable the pregnancies to be aged and fetal losses to be assessed. Pregnancy was confirmed by the presence of a viable fetus with a heartbeat. Each cow was assessed at 50 to $60 \mathrm{~d}$ after the breeding start date. Those cows not detected pregnant or with a possible pregnancy $<30 \mathrm{~d}$ old were enrolled for another pregnancy diagnosis at $\sim 80 \mathrm{~d}$ after breeding start date. A final pregnancy diagnosis including all cows was undertaken 43 to $44 \mathrm{~d}$ after the end of the breeding season by transrectal ultrasonography using a 5 to $15 \mathrm{MHz}$ probe (SonoScape S6V, Euromed Medical Systems) or Esi-Scan using a 3- to 7-MHz probe (BCF Technologies).

\section{Calving and Reproductive Performance}

Calving season date (expressed as the number of days from June 1 of each respective year) were calculated for each cow within each lactation. Submission rates (SR) were defined as the proportion of cows that calved and were present at the start of the seasonal breeding period and submitted for breeding within 21 (SR21) and $42($ SR42) d of the start of the seasonal breeding period. Pregnancy rates (PR) were defined as the proportion of cows diagnosed as pregnant by d 21 (PR21), 42 (PR42), and 63 (PR63). Final pregnancy rate (PRFin) was defined as the proportion of cows pregnant at the end of the breeding period of 98 and $76 \mathrm{~d}$ in lactation 1 and 2, respectively. All PR values were based on the pregnancy being viable at the final diagnosis, and thus excluded fetal and embryo losses. Conception rates $(\mathbf{C R})$ were defined as the proportion of cows that conceived within 21 (CR21) or $42 \mathrm{~d}$ of mating (CR42), and CR to first (CR1stAI) and second breeding (CR2ndAI).

Calving season day for each lactation was analyzed via 1-way analysis of covariance (ANCOVA; PROC MIXED). The model included FertBV (POS, NEG) as a fixed effect, and sire as random effect. In lactation 1 , cows that conceived via natural mating $(\mathrm{n}=9)$ were excluded from the analysis, as they were managed as a separate mob. The binary reproductive parameters were analyzed using logistic regression analysis (PROC GLIMMIX). The model included CSD and CIDR ( $1=$ yes, $0=$ no) as covariates for PR63 and PRFin, FertBV (POS, NEG) as a fixed effect, and sire as random effect. 
Results are presented as adjusted mean percentages and standard error of the mean, as well as relative risks (RR) and 95\% confidence intervals for POS versus NEG FertBV. Continuous parameters were subjected to survival analysis using a Cox proportional hazard model (Proc PHREG). The models included CSD and CIDR ( $1=$ yes, $0=$ no) as covariates, FertBV (POS, NEG) as a fixed effect, and sire as a random effect (frailty model). Results are presented as median days to insemination and conception as well as hazard ratio (HR), with 95\% confidence interval for POS versus NEG FertBV.

\section{Calving to First Ovulation}

The date of first ovulation was estimated based on the change in the milk progesterone concentrations from samples taken twice (lactation 1) or once (lactation 2) per week. The interval from calving to first ovulation (COV) was subsequently estimated using the estimated date of first ovulation for all cows (COV-all) and for those that had ovulated by d 42 of breeding (COV-6wk).

Milk Progesterone Concentrations. Milk progesterone concentrations were determined in milk samples collected from $14 \mathrm{~d}$ postcalving until $42 \mathrm{~d}$ of AI was complete. The milk samples were transported to the laboratory at the end of the sampling day and preserved via freezing. Samples were defatted using centrifugation (at $4^{\circ} \mathrm{C}, 1,900 \times g$ for $12 \mathrm{~min}$ ), and the skim milk was harvested. A commercial, double antibody RIA kit was used to determine skim milk progesterone concentrations in accordance with the manufacturer's instructions (ImmuChem Progesterone Double Antibody RIA). The inter- and intra-assay coefficients of variation were 11.3 and $7.5 \%$ for a high standard, 11.5 and $4.3 \%$ for the medium standard, and 12.1 and $9.2 \%$ for the low standard. The minimal detectable concentration was $0.44 \mathrm{ng} / \mathrm{mL}$.

Determining the Progesterone Cut Point. A cut point of $0.55 \mathrm{ng} / \mathrm{mL}$ for elevated skim milk progesterone content was chosen to indicate absence or presence of a functional corpus luteum (CL). This value was chosen after comparing progesterone concentrations in plasma and skim milk taken at the same time point at various stages of the estrous cycle of 20 cows. The relationship (skim milk concentrations $=0.441 \times$ plasma concentrations $+0.1129 ; \mathrm{R}^{2}=0.83$ ) indicated $0.55 \mathrm{ng} /$ $\mathrm{mL}$ progesterone in skim milk is equivalent to $1 \mathrm{ng} / \mathrm{mL}$ in plasma (Meier et al., 2021).

Determining the Calving to First Ovulation Interval. In lactation 1 , the date of ovulation was defined as the sample day when 2 consecutive or 2 of 3 skim milk progesterone concentrations were $>0.55 \mathrm{ng} / \mathrm{mL}$.
With week samples in lactation 2 , the date of ovulation was defined as the date of milk sampling where skim milk progesterone concentrations were $>0.55 \mathrm{ng} / \mathrm{mL}$ and where there was a pattern of elevated skim milk progesterone concentrations in the subsequent samples. The COV was the difference between calving date and ovulation date. Cows whose skim milk progesterone concentrations had not been elevated by the end of the progesterone sample regimen (38-39 d after the start of breeding) were assigned censored with the censored $\mathrm{COV}$ as day between calving to the start of breeding plus $39 \mathrm{~d}$.

Statistical Analyses. Two analyses were undertaken: all observations and those through to the completion of 6 -wk of breeding. Survival analysis was undertaken using Cox proportional hazard model (Proc PHReg). The statistical model included FertBV (POS or NEG) as fixed effect, sire as the random effect (frailty model), and CSD and CIDR ( $1=$ yes, $0=$ no) as the covariates. In lactation 1, 2 cows were excluded because they had no mating date. Data presented are median day to first ovulation and HR with $95 \%$ confidence intervals for POS versus NEG FertBV. The proportion cycling by the start of the breeding season were analyzed using binary logistic regression (Proc GLIMMIX) with FertBV (POS, NEG) as a fixed effect, sire as a random effect, and CSD as a covariate. Results are presented as adjusted mean percentages and standard errors, as well as RR and $95 \%$ confidence intervals for POS versus NEG FertBV.

\section{Uterine Health Measures}

Uterine Health Before Mating. Vaginal discharge was scored 3 wk before mating in lactation 1 (means \pm $\mathrm{SD} ; 19 \pm 1.5 \mathrm{~d})$ and lactation $2(22 \pm 0.0 \mathrm{~d})$. Vaginal content was sampled using a Metricheck device (Simcro Tech Ltd.); this device consisted of a 40-mm-diameter hemisphere of silicone attached to a 500-mm (length) stainless-steel rod. The vaginal content was scored $(0-5$, where $0=$ no sample, $1=$ clear mucus, and 5 $=$ purulent pus; McDougall et al., 2007). Cows were classified as having purulent vaginal discharge (PVD) during lactation 1 and 2 when the vaginal mucus was scored as $>1$, and defined as having normal vaginal discharge when scored $\leq 1$ (McDougall et al., 2007).

Detailed Uterine Health: Lactation 1. Detailed uterine health postcalving was monitored in lactation 1 and included both measurements of vaginal discharge (as described above) and endometrial cytology. Vaginal discharge was scored $4 \pm 1.0 \mathrm{~d}$ after calving (range $3-5$ d), $21 \pm 1.1 \mathrm{~d}$ after calving (range 19-23 d), and $42 \pm$ $1.1 \mathrm{~d}$ after calving (range 40-44 d). Endometrial cytology was evaluated at $21 \pm 1.0 \mathrm{~d}$ after calving (19-23 d), 
$42 \pm 1.1 \mathrm{~d}$ after calving (40-44 d), and $19 \pm 1.5 \mathrm{~d}$ before mating (17-21 d) as described previously (Burke et al., 2010; Meier et al., 2014). Two veterinary pathologists from Massey University (Palmerston North, New Zealand) determined the proportion of PMN cells on the slide. Areas of each slide that contained small clusters of epithelial cells (5-20 per cluster) were preferentially selected, and all identifiable nucleated cells counted (on average 260 cells were counted per slide; $<2 \%$ with $<200$ cells counted). No bias between the 2 pathologists was evident. The coefficient of variation was $35 \%$ estimated from 137 slides that were evaluated by both pathologists. Subclinical endometritis was diagnosed when cows had PMN $>9 \%$ at $21 \mathrm{~d}$ postcalving, $>7 \%$ at $42 \mathrm{~d}$ postcalving (Burke et al., 2010; McDougall et al., 2011 ), and $>2 \%$ at $21 \mathrm{~d}$ prebreeding.

Statistical Analyses. The Metricheck scores premating were analyzed with 1-way ANCOVA (Proc Mixed). Metricheck scores were $\log _{10}$ transformed to achieve better homogeneity of variance. Purulent vaginal discharge (Metricheck score $>1$ ) and subclinical endometritis (PMN $>9 \%$ at $21 \mathrm{~d}$ postcalving, $\mathrm{PMN}>7 \%$ at $42 \mathrm{~d}$ postcalving; Burke et al., 2010; McDougall et al., 2011) were analyzed using binary logistic regression (Proc GLIMMIX). The models included CSD as a covariate, FertBV (POS, NEG) as a fixed effect, and sire as a random effect. Results are presented as adjusted mean percentages and standard errors, as well as $\mathrm{RR}$ and $95 \%$ confidence intervals for POS versus NEG FertBV. For lactation 1, the postcalving Metricheck scores at 4, 21, and $42 \mathrm{~d}$ postcalving and PMN percent at 21 and $42 \mathrm{~d}$ postcalving were analyzed separately for each time point using 1-way ANCOVA with CSD as a covariate, FertBV (POS, NEG) as a fixed effect, and sire as a random effect.

\section{Cow Losses}

Animal losses and removals were classified throughout lactation 1 and 2 as follows: losses before calving (precalving due to abortions, unexpected death, or illness that required animals to be removed from the study), losses that occurred once the cow had calved (postcalving due to illness, death, voluntary culling by farm manager), and removal because the cows were not pregnant (cows failing to become pregnant during the seasonal breeding season). Analyses of the differences in the proportions of losses across the classifications were undertaken with the Fisher's exact $2 \times 2$ test (Social Science Statistics, 2019). Due to the relatively few losses classified as pre- or postcalving (lactation 1: precalving $<5 \%$, postcalving $<2 \%$; lactation 2 : precalving $<2 \%$, postcalving $<4 \%$ ), the analyses were restricted to the following:
- All losses (combining pre- and postcalving and not pregnant) for the combined lactations, lactation 1 and lactation 2, as a proportion of total cows expected to calve

- Losses (combined pre- and postcalving losses) excluding those cows removed for being not pregnant at the end of the seasonal breeding period for the combined lactations, lactation 1 and lactation 2, as a proportion of total heifers expected to calve

- Removal of cows for being not pregnant at the end of the seasonal breeding period for the combined lactations, lactation 1 and lactation 2 , as a proportion of total heifers expected to calve

\section{RESULTS}

\section{Calving Season Day and Calving Pattern}

The POS FertBV cows calved $4 \mathrm{~d}$ earlier in the first lactation and $12 \mathrm{~d}$ earlier in the second lactation compared with the NEG FertBV cows (CSD: $56 \pm 1.2 \mathrm{~d}$ vs. $60 \pm 1.3 \mathrm{~d} ; P<0.05 ; 67 \pm 1.8$ d vs. $79 \pm 2.2 \mathrm{~d} ; P<$ $0.001)$. The proportion of cows calved within the first 6 wk of calving was also greater for POS than NEG FertBV cows; this difference was particularly evident in lactation 2 (Figure 1).

\section{Uterine Health Postcalving During Lactation 1}

The FertBV status did not affect average Metricheck scores at either 4,21 , or $42 \mathrm{~d}$ postcalving $(4 \mathrm{~d}$, POS $=$ $2.1 \pm 0.11$ vs. $\mathrm{NEG}=2.3 \pm 0.11 ; P=0.06 ; 21 \mathrm{~d}$, POS $=1.8 \pm 0.08$ vs. NEG $=1.9 \pm 0.08 ; P=0.14 ; 42 \mathrm{~d}$, $\mathrm{POS}=1.3 \pm 0.05$ vs. $\mathrm{NEG}=1.4 \pm 0.06 ; P=0.54$ ). The proportion of cows with PVD declined with DIM but did not differ between POS and NEG FertBV cows at $4 \mathrm{~d}(50.6 \pm 3.96 \%$ vs. $58.9 \pm 3.93 \% ; P=0.16), 21$ d $(37.4 \pm 3.20 \%$ vs. $44.0 \pm 3.46 \% ; P=0.21)$, or $42 \mathrm{~d}$ postcalving $(19.3 \pm 2.65 \%$ vs. $21.8 \pm 3.02 \% ; P=0.64)$, respectively.

\section{Uterine Health Prebreeding (Lactation 1 and 2)}

At $21 \mathrm{~d}$ before breeding start, there were no differences in Metricheck scores between the POS and NEG FertBV cows in lactation 1 (POS $1.46 \pm 0.062$, NEG $1.47 \pm 0.065 ; P=0.996)$ or lactation 2 (POS $1.22 \pm$ 0.066 , NEG $1.19 \pm 0.093 ; P=0.824)$. There was also no difference in the proportion of POS or NEG FertBV cows with PVD in lactation 1 or lactation 2 (POS = $27.4 \pm 3.22 \%$ vs. $\mathrm{NEG}=26.3 \pm 3.26 \%, P=0.815$; $\mathrm{POS}=13.5 \pm 3.15 \%$ vs. $\mathrm{NEG}=18.8 \pm 4.35 \%, P=$ 0.325 , respectively). 
Overall, the POS FertBV cows had lower $(P<0.01)$ uterine PMN percent than NEG FertBV cows (POS $=18.9 \pm 4.65 \%, \mathrm{NEG}=24.1 \pm 4.58 \%)$ postcalving. Uterine PMN percent declined from $36.1 \pm 4.56 \%$ at $21 \mathrm{~d}$ postcalving to $6.9 \pm 4.62 \%$ at $42 \mathrm{~d}$ postcalving $(P$ $<0.001)$, but there was no interaction between FertBV and days postcalving $(P=0.56 ; 33.6 \%, 4.2 \%, 38.6 \%$, $9.6 \%$ for $21 \mathrm{~d}$ POS, $42 \mathrm{~d}$ POS, $21 \mathrm{~d}$ NEG, and $42 \mathrm{~d}$ NEG, respectively).

There was a significant interaction $(P<0.05)$ between FertBV and week postcalving for the proportion of cows with PMN $>9 \%$ at $21 \mathrm{~d}$ and $>7 \%$ at $42 \mathrm{~d}$ postcalving; $69.9 \pm 8.15 \%$ and $16.5 \pm 5.75 \%$ of POS FertBV cows were above the given thresholds at 21 and $42 \mathrm{~d}$ postcalving, respectively, and $74.0 \pm 7.40 \%$ NEG FertBV cows and $33.3 \pm 8.75 \%$ were above the threshold at $21-\mathrm{d}$ and $42-\mathrm{d}$ postcalving, respectively.
At 42-d postcalving, the risk of having $>7 \%$ PMN POS cows was $50 \%$ less in POS FertBV cows than in NEG FertBV cows $(\mathrm{RR}=0.50 ; 95 \%$ CI: $0.31-0.77 ; P$ $<0.001)$. More NEG FertBV cows were classified with elevated PMN percent (PMN > 2\%) $21 \mathrm{~d}$ before the breeding start date $(\mathrm{POS}=28.2 \pm 3.71 \%$; $\mathrm{NEG}=35.5$ $\pm 4.12 \%, P=0.027$; POS vs. NEG RR $=0.94 ; 95 \%$ CI: $0.82-1.05)$.

\section{Reproductive Outcomes}

Calving to First Ovulation (COV-all and COV-6wk). In lactation 1, 480 cows had COV estimates (COV-all), where 438 cows had COV-6wk (POS $=214 / 256$ cows and $\mathrm{NEG}=87 / 224$ cows $)$. In lactation 2, COV estimates were from 325 cows (COV-all), with 182/204 POS and 98/121 NEG FertBV (COV-6wk) un-
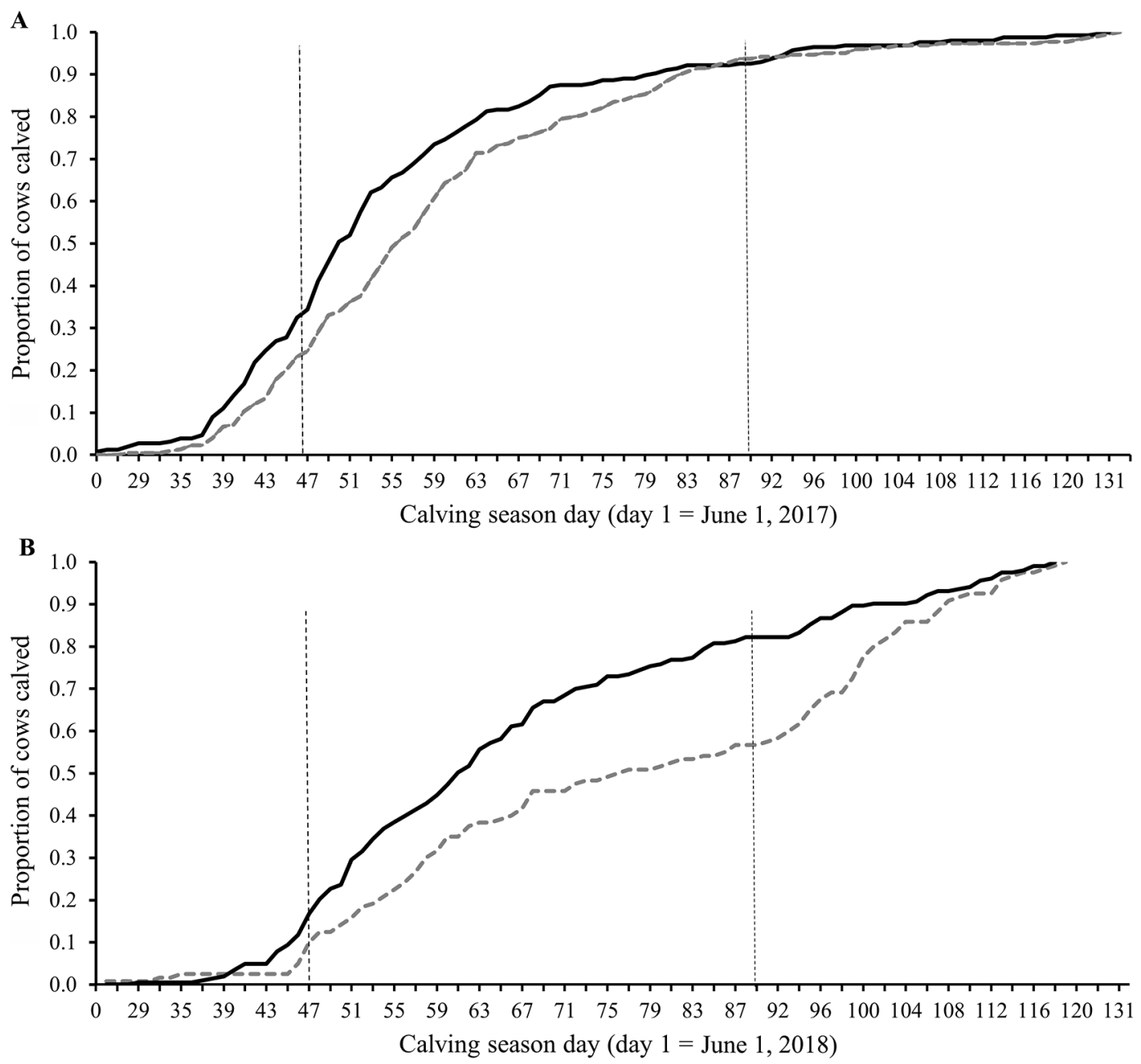

Figure 1. The proportion of cows calved by calving season day (CSD) for the positive (POS; solid line) and negative (NEG; dashed line) genetic merit for fertility traits in lactation 1 (A) and 2 (B). Parallel vertical bars identify the estimated calving start date for the herd at CSD 47 (based on start of breeding $+282 \mathrm{~d}$ for each year) and the point at $42 \mathrm{~d}$ of calving (CSD 89). The start of the seasonal breeding is CSD 130 . Main effects of fertility: lactation $1 P=0.001$, lactation $2 P<0.001$. Horizonal line represents $50 \%$ calved. 
censored, and the remaining cows were censored (POS $=22 / 204$ cows and NEG $=23 / 121$ cows).

Considering all animals, the median COV-all was 41 $\mathrm{d}$ for the POS and $60 \mathrm{~d}$ for the NEG FertBV cows $(P$ $<0.001)$ in the first lactation, and the median COV-all was $43 \mathrm{~d}$ for the POS and $53 \mathrm{~d}$ for the NEG FertBV cows in the second lactation $(P<0.01$; Figure $2 \mathrm{~A}$ and B). The median COV-6wk for cows that ovulated without intervention (uncensored), was $42 \mathrm{~d}$ for the POS FertBV and $51 \mathrm{~d}$ for the NEG FertBV cows $(P<$ $0.05)$ in lactation 1 and $39 \mathrm{~d}$ and $48 \mathrm{~d}$ for the cows of POS and NEG FertBV in lactation $2(P<0.01$; Figure $2 \mathrm{C}$ and $\mathrm{D})$.

Submission Rate. More POS FertBV cows were submitted during the first 21 and $42 \mathrm{~d}$ of seasonal breeding period compared with NEG FertBV cows in both lactation 1 and 2 (Table 2). The POS FertBV cows were $78 \%(\mathrm{RR}=1.78,95 \% \mathrm{CI}: 1.63-1.88)$ and $39 \%(\mathrm{RR}=1.39,95 \% \mathrm{CI}: 1.25-1.48)$ more likely to be bred in the first 3 wk of the seasonal breeding seasons in lactations 1 and 2, respectively, than NEG FertBV cows. Additionally, the POS FertBV cows were $74 \%$ $(\mathrm{RR}=1.74,95 \% \mathrm{CI}: 1.66-1.79)$ and $28 \%(\mathrm{RR}=1.28$, 95\% CI: $1.20-1.32)$ more likely to be bred in the first $42 \mathrm{~d}$ of the seasonal breeding period in lactations 1 and 2 , respectively.

Conception Rate. Conception rates to the first AI were not affected by FertBV in either lactation 1 or 2 (Table 2), but POS FertBV cows had a greater conception rate to second $\mathrm{AI}(P<0.001)$ and during the first $42 \mathrm{~d}$ of AI $(P=0.016$; Table 3$)$ in lactation 2 compared with NEG FertBV cows. Hence, the POS FertBV cows were $25 \%$ more likely to conceive in the first $42 \mathrm{~d}$ of breeding in the second lactation $(\mathrm{RR}=1.25,95 \% \mathrm{CI}$ : $1.06-1.38)$.

Pregnancy Rate. More POS FertBV cows became pregnant by 21 and $42 \mathrm{~d}$ of breeding than NEG cows in lactation 1, with $28 \%$ greater PR21 and $33 \%$ greater
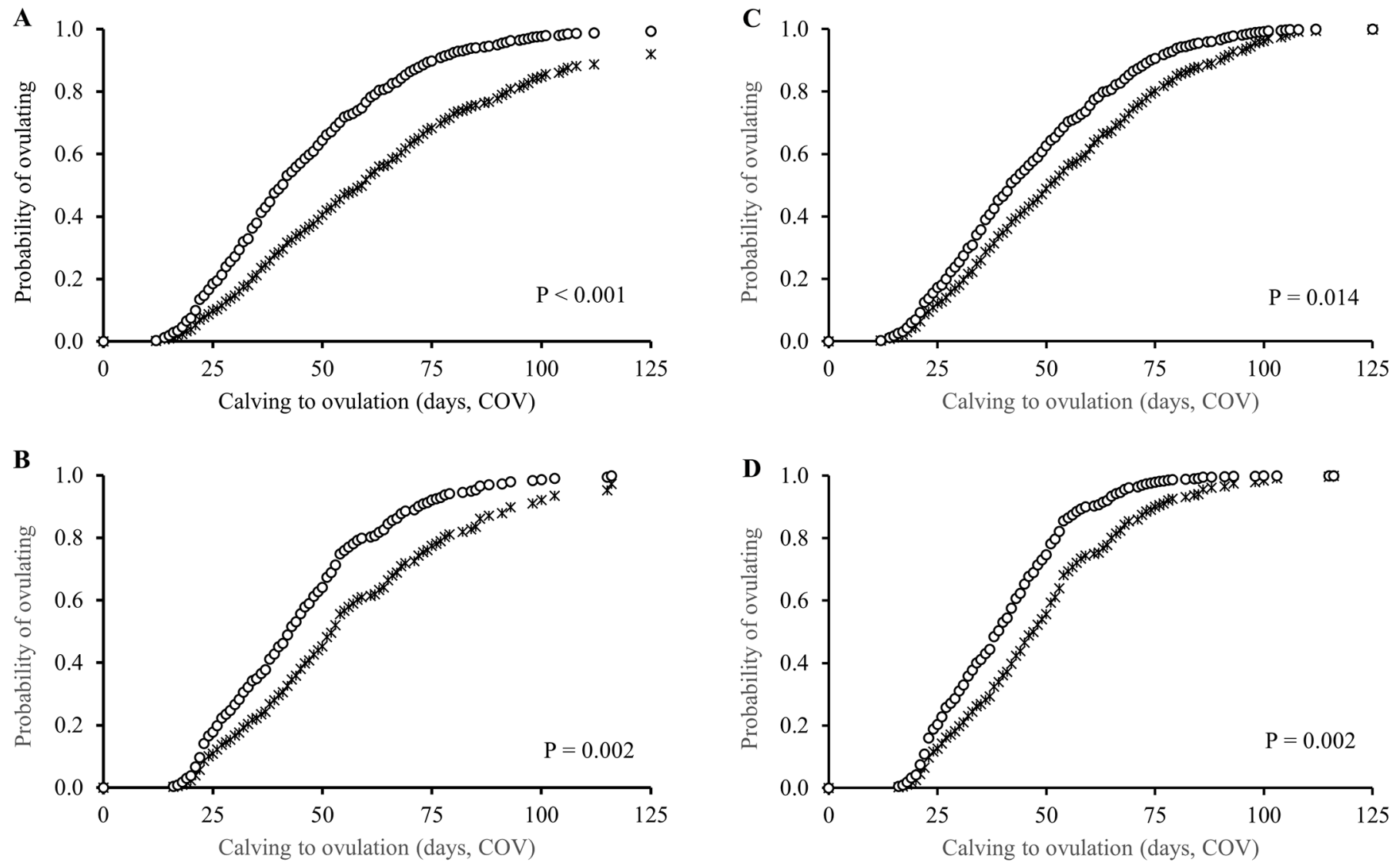

Figure 2. Probability of having ovulated [survival estimates for the interval from calving to ovulation based on skim milk progesterone based on twice weekly samples in lactation 1 and weekly samples in lactation 2 , in cows with positive (POS, O) and negative (NEG, *)] genetic merit for fertility traits for all cows in lactation 1 (A; POS: $\mathrm{n}=256$, NEG: $\mathrm{n}=224)$ and lactation $2(\mathrm{~B}$, POS $\mathrm{n}=256$, NEG $\mathrm{n}=224)$ and only uncensored cows in lactation 1 (C; POS: 214 of 256 cows, NEG: 87 of 224 cows) and 2 (D; POS: 182 of 204 cows, NEG: 98 of 121 cows). Uncensored cows were cows that reached the skim milk progesterone threshold $>0.55 \mathrm{ng} / \mathrm{mL}$ by 38 to $39 \mathrm{~d}$ after the start of seasonal breeding period. 
Table 2. The effect ${ }^{1}$ of genetic merit for fertility traits on the reproductive parameters in lactation 1 and 2

\begin{tabular}{|c|c|c|c|c|c|c|c|c|c|c|}
\hline Parameter $^{2}$ & \multicolumn{2}{|c|}{ Positive } & \multicolumn{2}{|c|}{ Negative } & \multicolumn{3}{|c|}{$P$-value } & \multicolumn{3}{|c|}{ Relative risk ${ }^{3}$} \\
\hline $\begin{array}{l}\text { Cows (n) } \\
\text { SR21 }\end{array}$ & 249 & - & 216 & - & - & & - & & & \\
\hline SR21 & 87 & 2.3 & 49 & 3.8 & $<0.001$ & $<0.002$ & - & 1.78 & 1.63 & 1.88 \\
\hline SR42 & 95 & 1.4 & 55 & 3.9 & $<0.001$ & 0.149 & - & 1.74 & 1.66 & 1.79 \\
\hline PR21 & 54 & 3.8 & 26 & 3.3 & $<0.001$ & $<0.002$ & - & 2.09 & 1.64 & 2.52 \\
\hline PRFin & 78 & 3.0 & 68 & 3.6 & 0.294 & 0.180 & 0.080 & 1.15 & 0.18 & 1.45 \\
\hline CR1stAI & 57 & 3.2 & 52 & 4.6 & 0.499 & 0.320 & - & 0.94 & 0.64 & 1.25 \\
\hline CR2ndAI & 43 & 4.9 & 46 & 6.5 & 0.696 & 0.921 & - & 1.28 & 0.12 & 2.12 \\
\hline CR21 & 64 & 3.3 & 54 & 4.9 & 0.335 & 0.289 & - & 1.19 & 0.14 & 1.81 \\
\hline CR42 & 71 & 3.0 & 62 & 4.4 & 0.333 & 0.247 & - & 1.15 & 0.17 & 1.59 \\
\hline Lactation 2 & & & & & & & & - & - & - \\
\hline Cows (n) & 204 & - & 121 & - & - & & - & & & \\
\hline PRFin & 86 & 2.8 & 72 & 5.0 & 0.238 & 0.100 & 0.092 & 1.19 & 0.11 & 1.39 \\
\hline CR1stAI & 54 & 3.8 & 51 & 5.9 & 0.814 & 0.158 & - & 1.62 & 1.30 & 1.80 \\
\hline CR2ndAI & 69 & 5.8 & 32 & 8.0 & 0.001 & 0.161 & - & 1.64 & 0.05 & 3.12 \\
\hline CR21 & 56 & 3.8 & 51 & 6.4 & 0.671 & 0.169 & - & 1.08 & 0.05 & 1.91 \\
\hline CR42 & 81 & 3.2 & 65 & 5.8 & 0.016 & $<0.001$ & - & 1.25 & 1.06 & 1.38 \\
\hline
\end{tabular}

${ }^{1}$ Data presented are the least squares means and standard error of the means, with the $P$-values representing the effect of genetic merit for fertility traits (positive, negative), calving season day (CSD; standardized day from June 1 each year) and reproductive treatment (CIDR).

${ }^{2}$ Binary reproductive parameters are presented as percentages (\%): SR = submission rate (percentage of eligible cows that were submitted for mating across 21 or $42 \mathrm{~d}$ of breeding); PR = pregnancy rate (percentage of eligible cows pregnant after 21, 42, 63 d (PR21, PR42, PR63) or at the end of breeding (PRFin); CR = conception rate (percentage of submitted cows that are pregnant), CR1stAI and CR2ndAI are the conception rates to first or second AI; CR21 and CR42 refer to the conception rate of the cows bred in the first 21 and $42 \mathrm{~d}$ of the seasonal breeding period.

${ }^{3}$ Relative risk (RR) with the $95 \%$ CI, with cows with positive vs. negative genetic merit for fertility traits.

${ }^{4}$ Cows were treated for anestrous (CIDR) if they were not mated after 6 wk of mating and had no detectable corpus luteum.

PR42 $(P<0.001 ;$ Table 3$)$. In the first lactation, the POS FertBV cows had a RR of 2.1 to 2.0 of being pregnant after 3 and 6 wk of breeding compared with the NEG FertBV cows (Table 3). Pregnancy rates in lactation 2 followed the same trend, with the POS FertBV cows having 8 to $10 \%$ more cows pregnant at the end of breeding compared with the NEG FertBV cows (Table 2).

Interval from Calving to First AI and Conception. The POS FertBV cows were mated $3 \mathrm{~d}$ earlier in the first lactation, and $2 \mathrm{~d}$ earlier in the second lactation $(P=0.025$ and $P=0.032$, respectively; Table 3$)$.

Table 3. Timing from calving and mating to first insemination and conception (median days and hazard ratio; HR) in cows with positive and negative genetic merit for fertility traits; $P$-values include the effect of genetic merit for fertility traits (fertility), calving season day (CSD; standardized day from June 1 each year), and reproductive treatment (CIDR)

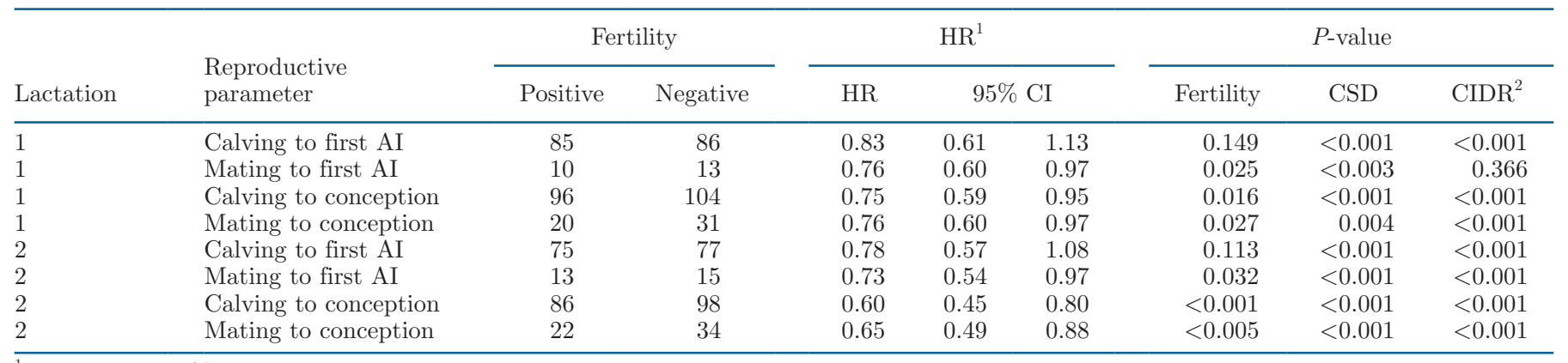

${ }^{1} \mathrm{HR}$ with the $95 \% \mathrm{CI}$, with cows with positive vs. negative genetic merit for fertility traits.

${ }^{2}$ Cows were treated for anestrous (CIDR) if they were not mated after 6 wk of mating and had no detectable corpus luteum. 
Table 4. Estimated DIM, 270-d milk, protein, and fat yields, as well as daily milk yields, milk composition, BW, and BCS for cows with positive (POS) or negative (NEG) genetic merit for fertility traits in lactation 1 (all first calving/primiparous) and lactation 2 (all second calving)

\begin{tabular}{|c|c|c|c|c|c|c|c|c|}
\hline Item & \multicolumn{3}{|c|}{ Lactation 1} & $\begin{array}{l}P \text {-value }{ }^{1} \\
\text { Fertility }\end{array}$ & \multicolumn{3}{|c|}{ Lactation 2} & $\begin{array}{l}P \text {-value } \\
\text { Fertility }\end{array}$ \\
\hline 270 -d protein yield $(\mathrm{kg})^{3}$ & 151 & 147 & 2.3 & 0.129 & 202 & 203 & 4.1 & 0.773 \\
\hline 270 -d fat yield $(\mathrm{kg})^{3}$ & 130 & 130 & 1.6 & 0.922 & 183 & 184 & 2.8 & 0.752 \\
\hline Milk yield (L/d) & 14.75 & 14.80 & 0.282 & 0.866 & 17.10 & 16.80 & 0.299 & 0.331 \\
\hline Protein $\%$ & 3.66 & 3.60 & 0.041 & 0.165 & 3.82 & 3.80 & 0.035 & 0.679 \\
\hline Fat $\%$ & 4.28 & 4.15 & 0.079 & 0.111 & 4.17 & 4.15 & 0.070 & 0.793 \\
\hline $\operatorname{SCC}\left(\log _{10} \times 10^{3}\right)$ & 4.75 & 4.75 & 0.056 & 0.931 & 4.70 & 4.73 & 0.035 & 0.479 \\
\hline $\mathrm{BW}, \mathrm{kg}$ & 442 & 434 & 2.2 & $<0.001$ & 488 & 484 & 2.4 & 0.116 \\
\hline $\mathrm{BCS}$ & 4.44 & 4.46 & 0.04 & 0.567 & 4.31 & 4.31 & 0.04 & 0.977 \\
\hline
\end{tabular}

${ }^{1} P$-values represent the effect of genetic merit for fertility

${ }^{2}$ Standard error of the difference.

${ }^{3}$ Estimated 270-d milk yield (L) and fat and protein yields $(\mathrm{kg})$ were calculated using the test interval method (ICAR, 2019).

Additionally, relative to mating, the POS FertBV cows conceived, on average, 9 and $12 \mathrm{~d}$ earlier than the NEG FertBV cows (Table 4).

\section{Reproductive Treatments}

The proportion of cows that required reproductive treatment after $42 \mathrm{~d}$ of the seasonal breeding period in lactation 1 and 2 was 41 and $24 \%$ greater for NEG FertBV cows than POS FertBV cows (lactation 1, POS $=5 \pm 1.5 \%$ vs. $\mathrm{NEG}=46 \pm 4.0 \% ; P<0.001$; lactation $2, \mathrm{POS}=6 \pm 1.8 \%$ vs. $\mathrm{NEG}=30 \pm 5.1 \%$; $P<$ 0.001). Therefore, POS FertBV cows had $89 \%(\mathrm{RR}=$ $0.11 ; 95 \%$ CI: $0.06-0.22)$ and $79 \%(\mathrm{RR}=0.21,95 \% \mathrm{CI}$ : 0.10-0.42) reduction in the risk of receiving a CIDR treatment after SR42 compared with the NEG FertBV cows.

\section{Days in Milk, 270-d Milk Yield, Milk Composition, and SCC}

Milk production variables were not affected by FertBV category, although there were significant FertBV by month interactions $(P<0.05)$ for milk fat percentage in lactation 1 and 2 and milk protein percentage in lactation 2 (Table 4, Figures 3 and 4). There was also a tendency for a FertBV by month interaction for $\log _{10}$ $\mathrm{SCC}$ in lactation $1(P=0.09)$.

\section{The BCS and BW}

Although average BCS was the same for POS and NEG FertBV cows [respectively, 4.44 and 4.46 [standard error of the difference (SED) $=0.0435]$ in lactation 1 , and 4.31 and $4.31(\mathrm{SED}=0.040)$ in lactation 2 ; Table
2], interactions between FertBV and month of lactation $1(P<0.001)$ and lactation $2(P<0.001)$ for BCS were evident and indicated different patterns of BCS change between the fertility lines from pre- to postcalving. Nonetheless, the differences in the BCS profiles were biologically small. The BCS of the NEG FertBV cows was $0.16(P<0.05)$ and $0.30(P<0.001)$ greater precalving in lactation 1 and 2 , respectively (Figure 1). In lactation 2, the BCS of the POS FertBV cows was 0.05 units greater $(P<0.05)$ at 5 mo postcalving and 0.15 BCS units greater through mo 3 to $5(P<0.01)$.

There were small differences in BW between the FertBV groups. On average, the POS FertBV cows were heavier in lactation $1(P<0.001)$; the cows had similar BW in lactation $2(P>0.05$; Table 2 ; Figure 5$)$. Cows in both FertBV groups gained 40 to $50 \mathrm{~kg}$ between first and second calving. The POS and NEG FertBV cows had similar BW at 1 and 2 mo precalving in lactation 1 $(P>0.05)$, but NEG FertBV cows were $7 \mathrm{~kg}$ heavier 1 mo precalving in lactation $2(P<0.05$; Figure 5$)$. From 1 to 9 mo postcalving in lactation 1 , the POS FertBV cows were 7 to $14 \mathrm{~kg}$ heavier $(P<0.001)$. In lactation 2 , the POS FertBV cows were $6 \mathrm{~kg}$ heavier in mo 1 to $2(P=0.06$ to 0.08$), 8$ to $13 \mathrm{~kg}$ heavier in mo 3 to 4 $(P=0.006)$, and 3 to $7 \mathrm{~kg}$ heavier in mo 6 to $9(P=$ 0.06 to 0.13$)$.

\section{Cow Removals}

The main reason for cow removal was their failure to become pregnant during the seasonal breeding period, accounting for 83 and $84 \%$ of total cow losses in lactations 1 and 2, respectively. Of the remaining losses, $13 \%$ occurred precalving in lactation 1 (between the period heifers were confirmed pregnant and expected 

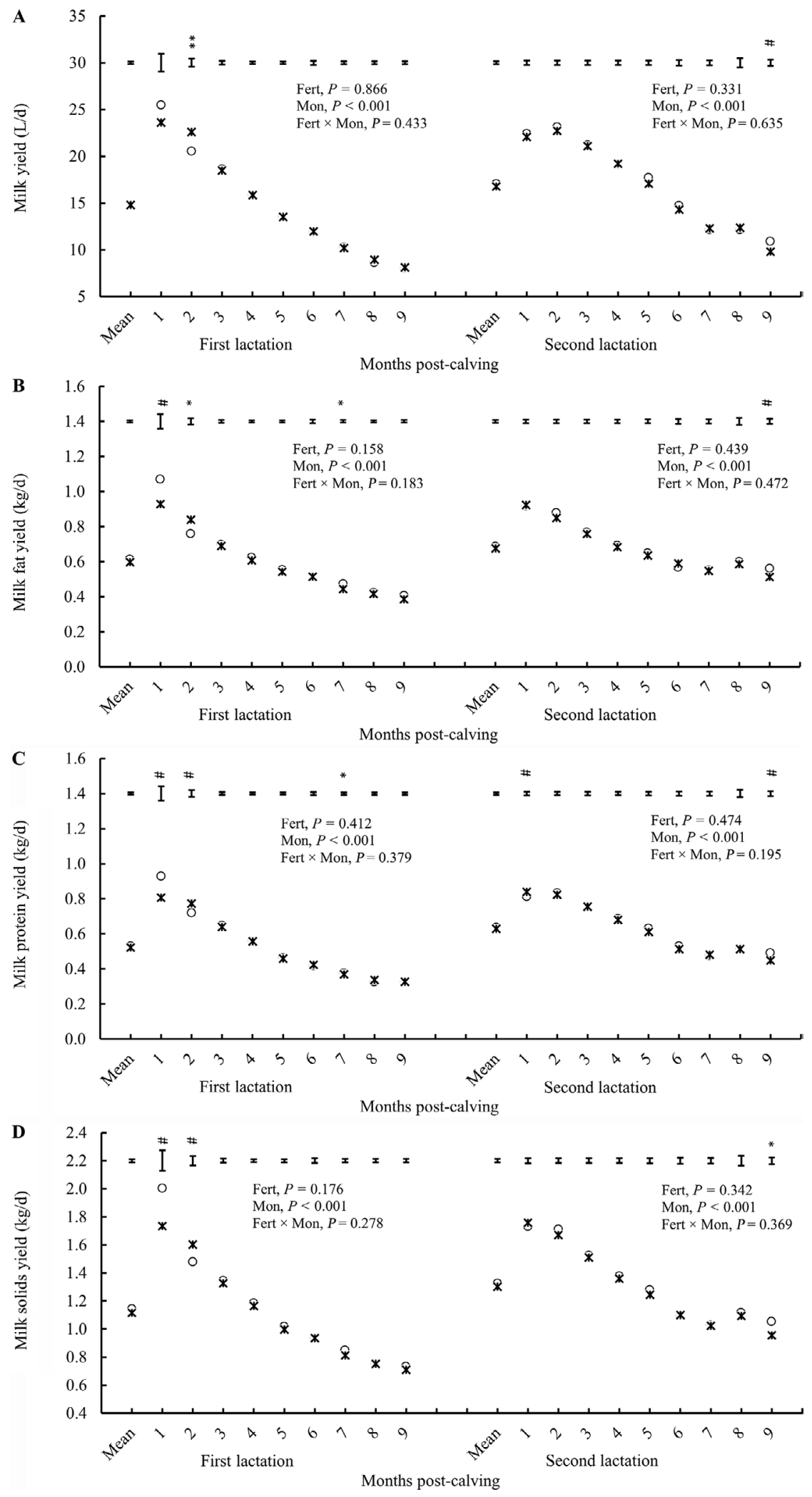

Figure 3. Effect of genetic merit for fertility traits [positive (POS) $\bigcirc$, negative (NEG) *] on (A) milk yield, (B) milk fat yield, (C) milk protein yield, and (D) milksolids yields for lactation 1 and 2. Data presented are the least squares means for POS and NEG. Error bars represent the standard error of the difference for each month. $P$-values presented include genetic merit for fertility traits (Fert), month (Mon), and fertility by month interaction (Fert $\times$ Mon) across the months within each lactation. Within month: $\# P<0.10,{ }^{*} P<0.05,{ }^{* *} P<0.001$. 

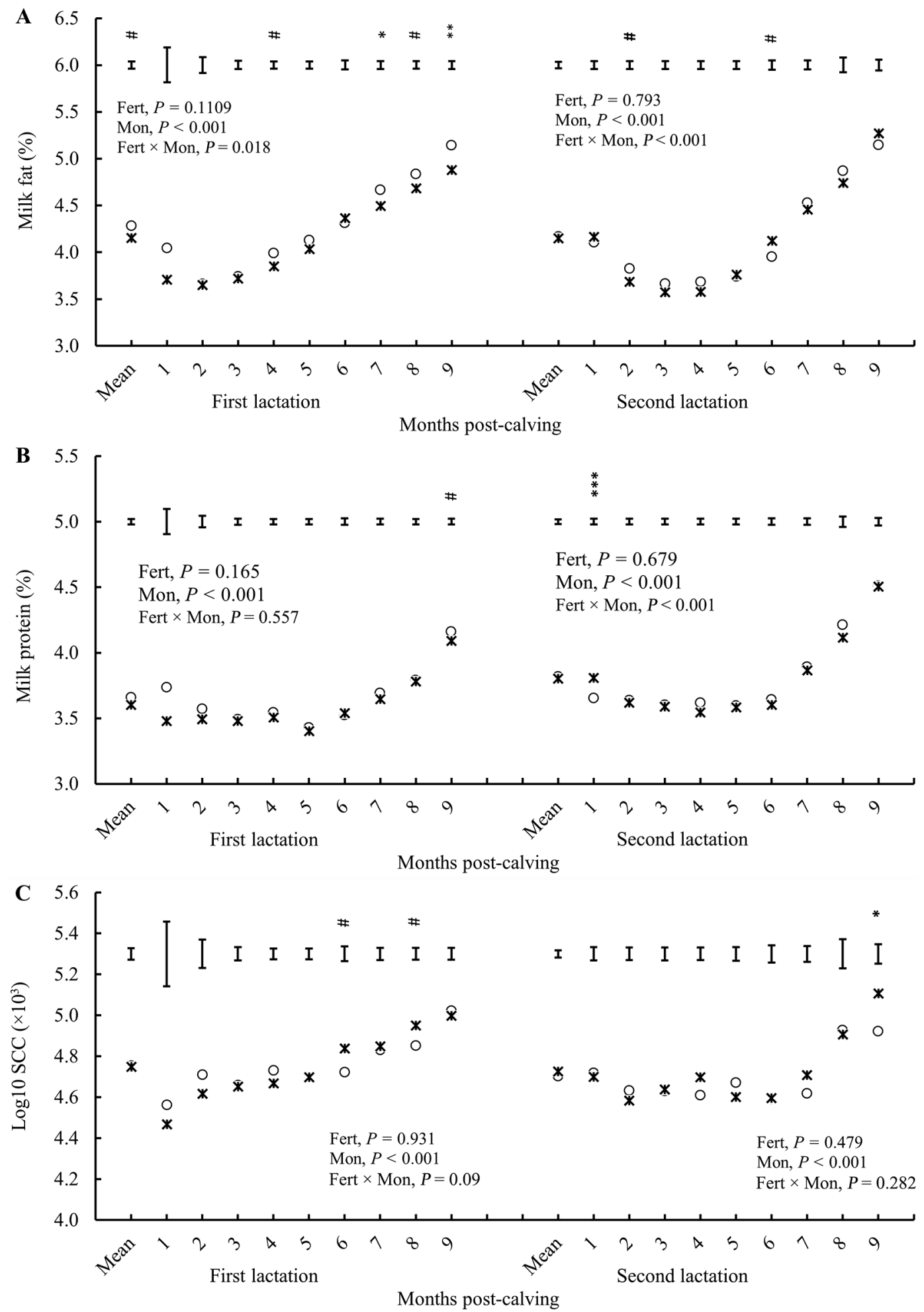

Figure 4. Effect of genetic merit for fertility traits [positive (POS) $\bigcirc$, negative (NEG) *] on milk (A) fat percentage, (B) protein percentage, and (C) SCC for lactation 1 and 2. Data presented are the least squares means for POS and NEG across and within month. Error bars represent the standard error of the difference for each month. $P$-values presented include genetic fertility (Fert), month (Mon), and fertility by month interaction (Fert $\times$ Mon). $\# P<0.10,{ }^{*} P<0.05,{ }^{* *} P<0.001$ 

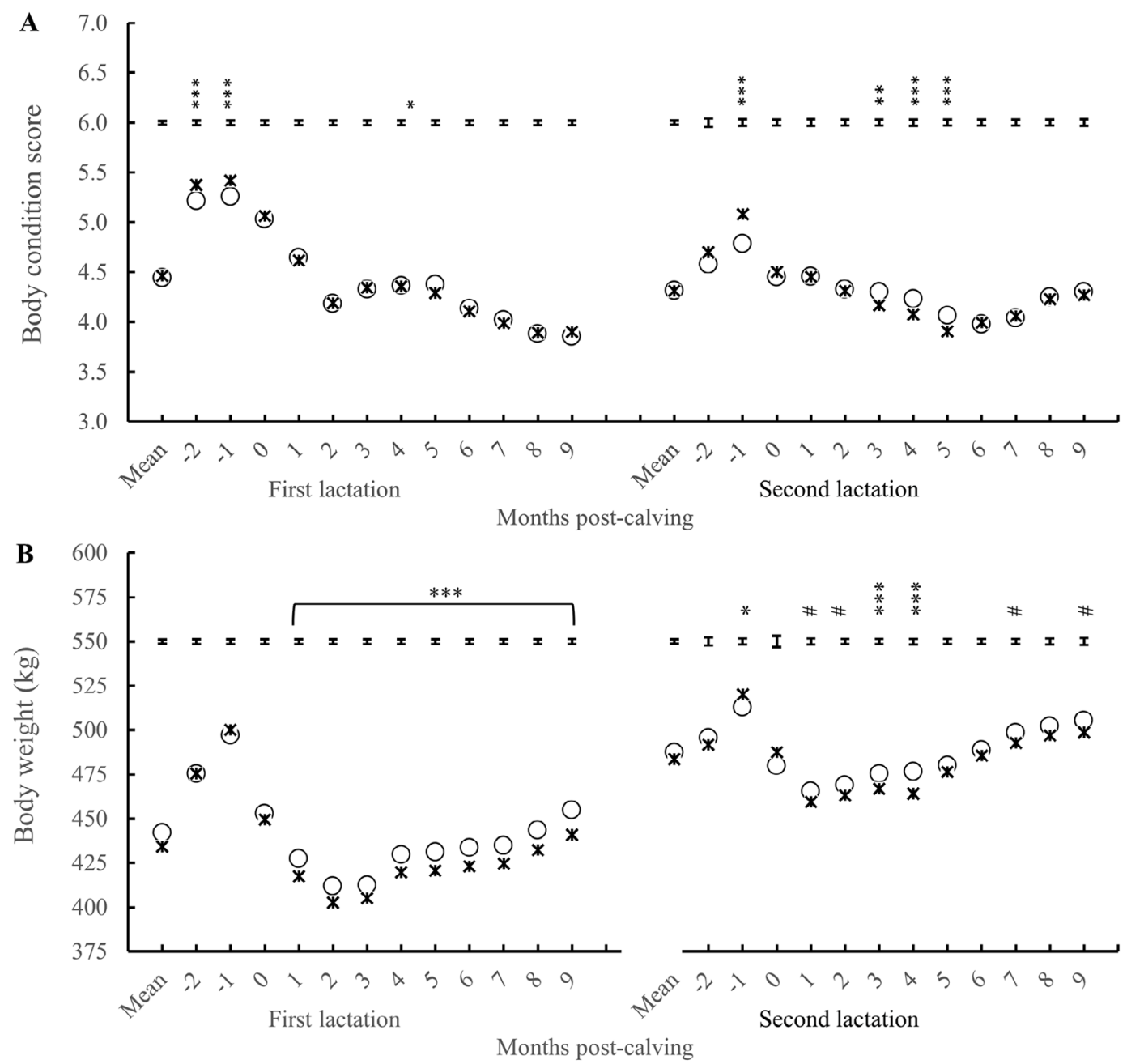

Figure 5. Body condition score (A) and BW (B) curves of the cows with positive $(\bigcirc)$ and negative $\left(^{*}\right)$ genetic merit for fertility traits over 2 lactations for each month 2 mo before calving to the end of their second lactation. Error bars depict standard error of deviations. BCS: lactation 1: fertility $P=0.567$, month $P<0.001$, fertility $\times$ month $P<0.001$, calving season day (CSD) $P=0.007$; lactation 2 : fertility $P=0.977$, month $P<0.001$, fertility $\times$ month $P<0.001$, CSD $P<0.001$. Within month: ** $P<0.01, * * * P<0.001$. BW: lactation 1 : fertility $P<0.001$, month $P<0.001$, fertility $\times$ month $P<0.001$, CSD $P<0.001$; lactation 2 : fertility $P=0.116$, month $P<0.001$, fertility $\times$ month $P<0.001$, CSD $P<0.001$. Within month: ${ }^{\#} P>0.05$ and $P<0.10,{ }^{*} P<0.05,{ }^{* * *} P<0.001$.

calving date), with the remaining $4 \%$ postcalving. During lactation $2,4 \%$ of cows were removed precalving (between the pregnancy being confirmed in lactation 1 and expected calving date in lactation 2), and $12 \%$ postcalving (Figure 6).

\section{DISCUSSION}

Genetic selection in dairy cattle has focused on productivity and, more recently, robustness or resilience traits, resulting in significant gains in milk production traits (volume and milksolids) and minor gains in reproductive traits (Miglior, 2002; Miglior et al., 2005; Pryce et al., 2014). Cows with divergent FertBV were bred and managed to minimize the confounding effects of milk production, body condition, and ancestry. The differences in reproductive physiology were expressed more due to the delayed reproductive interventions. Selection for FertBV affected the interval from calving to first ovulation, submission rate, the timing of conception, and PR. The FertBV did affect uterine health, with the difference in uterine health likely to have negligible effects on the reproductive differences reported. Similarly, minor differences in milk production, milk composition, and BW and BCS between the POS FertBV and NEG FertBV groups are relatively immaterial.

Selection for FertBV affects the resumption of estrous cycles postcalving. The substantial effect reported identified that POS FertBV is associated with shorter 


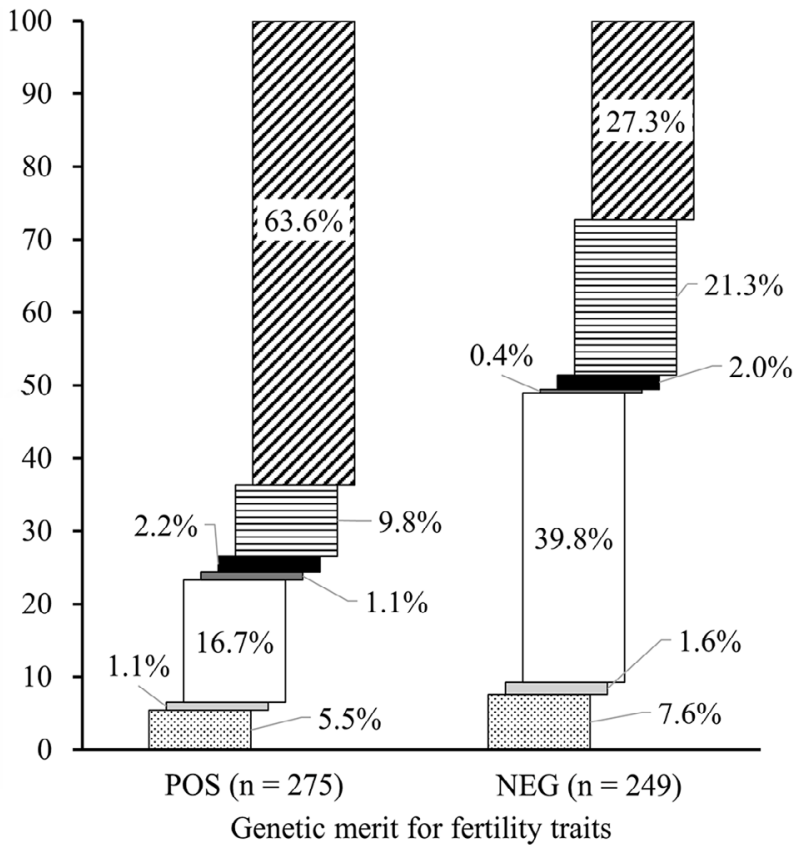

$\square$ Pregnant at the end of lactation 2

$\boxminus$ Not pregnant - lactation 2

- Removed after second calving

$\square$ Removed prior to second calving

$\square$ Not pregnant - lactation 1

$\square$ Removed after first calving

Removed prior to first calving

Figure 6. Distribution of cows according to time of removal for the positive (POS) and negative (NEG) genetic merit for fertility traits relative to cows expected to calve $[\mathrm{n}=524$; POS $\mathrm{n}=275(100 \%)$, NEG $\mathrm{n}=249(100 \%)]$.

COV and lower reliance on reproductive treatments. Previous studies have identified that genetic ancestry influences ovulation postcalving. Macdonald et al. (2008) compared New Zealand with North American strains of HF dairy cows; the North American strain ovulated earlier, yet this did not translate into greater PR. In a more recent study, the improved reproductive performance of elite cows (cows within the top $5 \%$ of the Irish Economic Breeding Index) occurred in the absence of an effect of genetic group on ovulation postcalving (O'Sullivan et al., 2020). This may reflect the relative short mean calving to ovulation intervals $(>28$ d) reported in this study. Nevertheless, sufficient evidence supports the positive effects of earlier ovulation postcalving on reproductive outcomes similar to those reported here (Moore et al., 2014; Bruinjé et al., 2019). The POS FertBV cows with shorter COV resulted in more cows being on their second or third ovulation at breeding, which enhances conception rate (Thatcher and Wilcox, 1973; Burke et al., 2012). These phenotypic differences in COV suggest that the association between short COV and FertBV exists. To what extent shorter $\mathrm{COV}$ is delivered via genetic selection is unclear. Under current approaches, functional traits such as fertility represent $<20 \%$ of an overall index (e.g., FertBV is $13 \%$ of the NZ Breeding Worth).

Based on the results presented, selection for POS FertBV will shorten the time from calving to ovulation. However, what remains unclear is whether including a COV trait in the FertBV would provide additional benefit to the current approach. Traits based on elevations in milk progesterone concentration to estimate the timing between calving to first luteal activity have reported heritability of 0.13 to 0.30 , with the higher heritability evident when the frequency of progesterone sampling increases (Darwash et al., 1997; Royal et al., 2002; Petersson et al., 2007). Although these studies used traits that are expensive to capture, their heritability means they continue to be of interest, particularly if data collection becomes cost-effective.

Overall, the costlier progesterone-based trait is better compared with farmer-recorded traits. However, the importance of the ease and cost of collecting samples and undertaking progesterone analyses is an important consideration when collecting sufficient phenotypes to assess and select for ovulation traits. In the meantime, to test the utility of farmer-recorded estrus events more fully, an approach that incentivizes farmers to collect these data could be beneficial. Alternatively, measures collected using automated data collection from activity devices could be a viable alternative (Løvendahl and Chagunda, 2009; Ismael et al., 2016).

The failure to ovulate or late ovulation was a key factor contributing to the reduced reproductive performance of seasonal calving dairy herds, and treating ovulation failure (anestrus) can provide benefits (Verkerk, 2003; Chagas et al., 2007). However, using hormonal interventions to manage ovulation failures is 
often costly and may become unacceptable by consumers in the future. Hence, having a genetic solution that achieves this more progressively may become increasingly important where consumer perceptions influence dairy management.

The FertBV targets conception rate indirectly through submission and pregnancy traits. Therefore, a lack of a consistent difference in conception rate between the POS and NEG FertBV cows is not surprising. Conception is not a key factor contributing to the difference in reproductive performance between the POS FertBV and NEG FertBV cow. However, there is an effect of FertBV on time to conception. Therefore, it is days in milk at conception, and not conception rate, that was associated with FertBV. This result is similar to that reported earlier, where days to conception was shorter in cows selected for shorter calving interval (Fert+; Cummins et al., 2012). Previous studies identified that conception and pregnancy rate traits exploit different reproductive pathways (Veronese et al., 2019), supporting the concept that conception traits can improve reproductive outcomes if included in selection indices. High CR are particularly crucial for late-calving cows to become pregnant in the seasonal breeding period. With conception rate traits not currently included in genetic selection indices in New Zealand, further work is required to evaluate the benefits of including conception traits. Ideally, cows would express moderate COV (see below) and high CR at the first or second insemination.

When evaluated using cytology, FertBV POS cows had superior uterine health $42 \mathrm{~d}$ postcalving, yet there was no difference in clinical endometritis among the FertBV groups. This inconsistency is surprising as Fert+ cows had superior uterine health, with superior mucus score and uterine cytology compared with cows selected for extended calving interval (Moore et al., 2014). Both clinical endometritis and subclinical endometritis negatively affect reproductive outcomes individually and in combination (McDougall et al., 2007; Dubuc et al., 2010). Subclinical endometritis (high PMN \%) is associated with poor reproductive outcomes, including delayed ovulation postcalving and reduced CR (Burke et al., 2010; Dubuc et al., 2010; McDougall et al., 2011, 2020). This negative effect of subclinical endometritis on ovarian function may in part explain the delayed ovulation of the NEG FertBV cows. The bacterial contamination of the endometrium is associated with ovarian dysfunction, including delayed LH release, decreased follicle size, and effects on steroidogenesis and delayed ovulation (Sheldon et al., 2002; Williams et al., 2007). In the absence of detailed bacteriological analyses, the ovarian dysfunction in NEG FertBV cows was not due to a high endometritis incidence. The current study provides valuable insights into the association between FertBV and uterine health. It remains to be determined whether selection for superior uterine health has benefits beyond those already captured indirectly via the FertBV.

The seasonal BCS and BW changes and the interaction between FertBV and month of lactation for these parameters identified minor effects of FertBV on BCS and BW. The current study used strategies to limit BCS and BW variation to reduce these parameters' confounding effects on reproductive outcomes. Considering this approach, the NEG FertBV cows lost more body condition postcalving. This result aligns with previous research that identified cows selected for extended calving interval had lower BCS than their Fert+ counterparts (Cummins et al., 2012). Although this was a significant effect, the effect of this difference in BCS on reproductive outcomes was minimal and expected to account for less than $10 \%$ of the reported difference in PR42. Based on previous work, for every 0.5 BCS unit lost in early lactation, PR42 decreased by $3 \%$ (Roche et al., 2007). Hence, differences in BCS and BW among the POS and NEG FertBV cows explained $3 \%$ of the difference in PR42 between the POS and NEG FertBV cows. Therefore, although significant, the BCS and BW changes reported are unlikely to be drivers of the reproductive differences reported.

\section{CONCLUSIONS}

Cows with positive genetic merit for fertility traits had shorter intervals from calving to ovulation and a greater prebreeding cycling rate; these resulted in greater submission and PR in pasture-based herds with seasonal calving. There was no difference in rates of clinical endometritis, and there were small differences in subclinical endometritis. Milk production was similar between treatments, and the small differences in BW and BCS were transient and unlikely to materially affect fertility outcomes. On its own, having an easy-to-measure phenotype for time to ovulation postcalving could enhance selection for fertility in seasonal, pasture-based dairy systems. However, including traits associated with the timing of ovulation should provide the best outcomes for dairy systems dependent on seasonal calving. The differences in reproductive outcomes measured in the current experiment demonstrate the potential for improving herd reproductive performance through improvement in genetic merit for fertility.

\section{ACKNOWLEDGMENTS}

The authors acknowledge the invaluable support of the DairyNZ Ltd. (Hamilton, New Zealand) technical 
and farm teams that supported the data collection for this study; in particular, Stuart Morgan, Kelly Collier, Kate Watkins, Olivia Jordan, and Dagmar Elliott were pivotal in the phenotyping. This work was supported by the farm management and farm team at AgResearch's Tokanui Research Farm (Tokanui, New Zealand) undertaking the research protocols and looking after the cows on a day-to-day basis. Livestock Improvement Corporation Ltd. (LIC, Hamilton, New Zealand) are kindly acknowledged for providing the Breeding Worth and Breeding Values for the cows. This work was funded by dairy farmers through DairyNZ Incorporated (CB1804) with matched cofunding from the Ministry of Business, Innovation and Employment (DRCX1302) and aligned Strategic Science Investment Fund (SSIF) funding from AgResearch (Hamilton, New Zealand). Other support and resources were provided by LIC and CRV Ambreed (Hamilton, New Zealand). The input of Lorna McNaughton, Richard Spelman, Katie Eketone, Anna Burke, Rhiannon Handcock, and Jack Hooper from LIC, as well as Jeremy Bryant (formally DairyNZ), Ken Dodds (AgResearch, Mosgiel, New Zealand), and Phil Beatson (CRV Ambreed, Hamilton, New Zealand) during set up of the herd with divergent genetic merit for fertility is recognized. Finally, the dairy farmers who contributed to the establishment of this research herd through their involvement in the contract breeding program to generate the animals are acknowledged. The authors have not stated any conflicts of interest.

\section{REFERENCES}

Berry, D. P., M. P. Coffey, J. E. Pryce, Y. de Haas, P. Lovendahl, N. Krattenmacher, J. J. Crowley, Z. Wang, D. Spurlock, K. Weigel, K. Macdonald, and R. F. Veerkamp. 2014a. International genetic evaluations for feed intake in dairy cattle through the collation of data from multiple sources. J. Dairy Sci. 97:3894-3905. https://doi .org/10.3168/jds.2013-7548.

Berry, D. P., E. Wall, and J. E. Pryce. 2014b. Genetics and genomics of reproductive performance in dairy and beef cattle. Animal 8(Suppl 1.):105-121. https://doi.org/10.1017/S1751731114000743.

Bruinjé, T. C., M. G. Colazo, E. S. Ribeiro, M. Gobikrushanth, and D. J. Ambrose. 2019. Using in-line milk progesterone data to characterize parameters of luteal activity and their association with fertility in Holstein cows. J. Dairy Sci. 102:780-798. https://doi .org/10.3168/jds.2018-14654.

Burke, C. R., S. Meier, S. McDougall, C. Compton, M. Mitchell, and J. R. Roche. 2010. Relationships between endometritis and metabolic state during the transition period in pasture-grazed dairy cows. J. Dairy Sci. 93:5363-5373. https://doi.org/10.3168/jds.2010-3356.

Burke, C. R., S. Meier, and R. Pellow. 2012. Use of progesterone to investigate factors affecting conception rates in a large, pasturegrazed dairy herd. Pages 45-50 in Proc. N.Z. Soc. Anim. Prod. New Zealand Soc. Anim. Prod.

Chagas, L. M., J. J. Bass, D. Blache, C. R. Burke, J. K. Kay, D. R. Lindsay, M. C. Lucy, G. B. Martin, S. Meier, F. M. Rhodes, J. R. Roche, W. W. Thatcher, and R. Webb. 2007. Invited review: New perspectives on the roles of nutrition and metabolic priorities in the subfertility of high-producing dairy cows. J. Dairy Sci. 90:4022-4032. https://doi.org/10.3168/jds.2006-852.
Cole, J. B., and P. M. VanRaden. 2018. Symposium review: Possibilities in an age of genomics: The future of selection indices. J. Dairy Sci. 101:3686-3701. https://doi.org/10.3168/jds.2017-13335.

Craig, H. J. B., K. Stachowicz, M. Black, M. Parry, C. R. Burke, S. Meier, and P. R. Amer. 2018. Genotype by environment interactions in fertility traits in New Zealand dairy cows. J. Dairy Sci. 101:10991-11003. https://doi.org/10.3168/jds.2017-14195.

Cummins, S. B., P. Lonergan, A. C. Evans, D. P. Berry, R. D. Evans, and S. T. Butler. 2012. Genetic merit for fertility traits in Holstein cows: I. Production characteristics and reproductive efficiency in a pasture-based system. J. Dairy Sci. 95:1310-1322. https://doi.org/ $10.3168 /$ jds.2011-4742.

DairyNZ. 2017a. Breeding values. Accessed Aug. 4, 2017. https://www .dairynz.co.nz/animal/animal-evaluation/interpreting-the-info/ breeding-values.

DairyNZ. 2017b. Genetic Trends in the National Herd. Accessed Mar. 31, 2017. https://www.dairynz.co.nz/animal/animal-evaluation/ cow-and-herd-averages/.

DairyNZ. 2018. Description of National Genetic Evaluation Systems: Female Fertility. Accessed May 4, 2018. https://www.dairynz.co .nz/animal/animal-evaluation/interpreting-the-info/breeding -values/.

Darwash, A. O., G. E. Lamming, and J. A. Woolliams. 1997. Estimation of genetic variation in the interval from calving to postpartum ovulation of dairy cows. J. Dairy Sci. 80:1227-1234. https://doi .org/10.3168/jds.S0022-0302(97)76051-X.

Dennis, N. A., K. Stachowicz, B. Visser, F. S. Hely, D. K. Berg, N. C. Friggens, P. R. Amer, S. Meier, and C. R. Burke. 2018. Combining genetic and physiological data to identify predictors of lifetime reproductive success and the effect of selection on these predictors on underlying fertility traits. J. Dairy Sci. 101:3176-3192. https:/ /doi.org/10.3168/jds.2017-13355.

Dubuc, J., T. F. Duffield, K. E. Leslie, J. S. Walton, and S. J. LeBlanc. 2010. Definitions and diagnosis of postpartum endometritis in dairy cows. J. Dairy Sci. 93:5225-5233. https://doi.org/10 $.3168 /$ jds.2010-3428.

Egger-Danner, C., J. B. Cole, J. E. Pryce, N. Gengler, B. Heringstad, A. Bradley, and K. F. Stock. 2015. Invited review: Overview of new traits and phenotyping strategies in dairy cattle with a focus on functional traits. Animal 9:191-207. https://doi.org/10.1017/ S1751731114002614.

Harris, B. L., J. E. Pryce, Z. Z. Xu, and W. A. Montgomerie. 2006. Development of new fertility breeding values in the dairy industry. Pages 107-112 in Proc. N. Z. Soc. Anim. Prod. New Zealand Soc. Anim. Prod.

ICAR. 2019. Procedure 2 of Section 2 of ICAR Guidelines Computing of Accumulated Lactation Yield. Accessed Sep. 28, 2019. https: //www.icar.org/Guidelines/02-Procedure-2-Computing-Lactation -Yield.pdf.

Ismael, A., E. Strandberg, B. Berglund, M. Kargo, A. Fogh, and P. Løvendahl. 2016. Genotype by environment interaction for activity-based estrus traits in relation to production level for Danish Holstein. J. Dairy Sci. 99:9834-9844. https://doi.org/10.3168/jds .2016-11446.

Kinghorn, B. P. 2011. An algorithm for efficient constrained mate selection. Genet. Sel. Evol. 43:4. https://doi.org/10.1186/1297-9686 $-43-4$

LIC. 2019a. Short gestation length semen. Accessed Jan. 29, 2020. https://www.lic.co.nz/products-and-services/artificial-breeding/ short-gestation-length-semen/.

LIC. 2019b. How to herd test. Accessed Oct. 10, 2019. https://www.lic .co.nz/products-and-services/herd-testing/how-herd-test/.

Løvendahl, P., and M. G. Chagunda. 2009. Short communication: Genetic variation in estrus activity traits. J. Dairy Sci. 92:4683-4688. https://doi.org/10.3168/jds.2008-1736.

Macdonald, K. A., and J. R. Roche. 2004. Condition scoring made easy: Condition scoring for dairy herds. 1st ed. Dexcel Limited.

Macdonald, K. A., G. A. Verkerk, B. S. Thorrold, J. E. Pryce, J. W. Penno, L. R. McNaughton, L. J. Burton, J. A. Lancaster, J. H. Williamson, and C. W. Holmes. 2008. A comparison of three strains of Holstein-Friesian grazed on pasture and managed under 
different feed allowances. J. Dairy Sci. 91:1693-1707. https://doi .org/10.3168/jds.2007-0441.

Macmillan, K. L., V. K. Taufa, D. R. Barnes, A. M. Day, and R. Henry. 1988. Detecting estrus in synchronized heifers-using tailpaint and an aerosol raddle. Theriogenology 30:1099-1114. https://doi .org/10.1016/0093-691X(88)90285-3.

McDougall, S., D. Aberdein, A. Bates, and C. R. Burke. 2020. Prevalence of endometritis diagnosed by vaginal discharge scoring or uterine cytology in dairy cows and herds. J. Dairy Sci. 103:65116521. https://doi.org/10.3168/jds.2019-18048.

McDougall, S., H. Hussein, D. Aberdein, K. Buckle, J. Roche, C. Burke, M. Mitchell, and S. Meier. 2011. Relationships between cytology, bacteriology and vaginal discharge scores and reproductive performance in dairy cattle. Theriogenology 76:229-240. https:// doi.org/10.1016/j.theriogenology.2010.12.024.

McDougall, S., R. Macaulay, and C. Compton. 2007. Association between endometritis diagnosis using a novel intravaginal device and reproductive performance in dairy cattle. Anim. Reprod. Sci. 99:923. https://doi.org/10.1016/j.anireprosci.2006.03.017.

Meier, S., L. R. McNaughton, R. Handcock, P. R. Amer, P. R. Beatson, J. R. Bryant, K. G. Dodds, R. Spelman, J. R. Roche, and C. R. Burke. 2021. Heifers with positive genetic merit for fertility traits reach puberty earlier and have a greater pregnancy rate than heifers with negative genetic merit for fertility traits. J. Dairy Sci. 104:3707-3721. https://doi.org/10.3168/jds.2020-19155.

Meier, S., N. V. Priest, C. R. Burke, J. K. Kay, S. McDougall, M. D. Mitchell, C. G. Walker, A. Heiser, J. J. Loor, and J. R. Roche. 2014. Treatment with a nonsteroidal anti-inflammatory drug after calving did not improve milk production, health, or reproduction parameters in pasture-grazed dairy cows. J. Dairy Sci. 97:29322943. https://doi.org/10.3168/jds.2013-7838.

Miglior, F. 2002. Overview of different breeding objectives in various countries. Pages 1-9 in Proc. World Holst. Fries. Fed., World Holst. Fries. Fed.

Miglior, F., B. L. Muir, and B. J. Van Doormaal. 2005. Selection indices in Holstein cattle of various countries. J. Dairy Sci. 88:12551263. https://doi.org/10.3168/jds.S0022-0302(05)72792-2.

Moore, S. G., T. Fair, P. Lonergan, and S. T. Butler. 2014. Genetic merit for fertility traits in Holstein cows: IV. Transition period, uterine health, and resumption of cyclicity. J. Dairy Sci. 97:27402752. https://doi.org/10.3168/jds.2013-7278.

O'Sullivan, M., S. T. Butler, K. M. Pierce, M. A. Crowe, K. O'Sullivan, R. Fitzgerald, and F. Buckley. 2020. Reproductive efficiency and survival of Holstein-Friesian cows of divergent Economic Breeding Index, evaluated under seasonal calving pasture-based management. J. Dairy Sci. 103:1685-1700. https://doi.org/10.3168/jds 2019-17374.

Petersson, K. J., B. Berglund, E. Strandberg, H. Gustafsson, A. P. Flint, J. A. Woolliams, and M. D. Royal. 2007. Genetic analysis of postpartum measures of luteal activity in dairy cows. J. Dairy Sci. 90:427-434. https://doi.org/10.3168/jds.S0022-0302(07)72644-9.

Pryce, J. E., R. Woolaston, D. P. Berry, E. Wall, M. Winters, R. Butler, and M. Shaffer. 2014. World Trends in Dairy Cow Fertility.
Pages 1-6 in World Congr. Genet. Appl. Livest. Prod., Am. Soc. Anim. Sci.

Roche, J. R., P. G. Dillon, C. R. Stockdale, L. H. Baumgard, and M. J. VanBaale. 2004. Relationships among international body condition scoring systems. J. Dairy Sci. 87:3076-3079. https://doi.org/ 10.3168/jds.S0022-0302(04)73441-4.

Roche, J. R., K. A. Macdonald, C. R. Burke, J. M. Lee, and D. P. Berry. 2007. Associations among body condition score, body weight, and reproductive performance in seasonal-calving dairy cattle. J. Dairy Sci. 90:376-391. https://doi.org/10.3168/jds.S0022 -0302(07)72639-5

Royal, M. D., J. E. Pryce, J. A. Woolliams, and A. P. Flint. 2002. The genetic relationship between commencement of luteal activity and calving interval, body condition score, production, and linear type traits in Holstein-Friesian dairy cattle. J. Dairy Sci. 85:3071-3080. https://doi.org/10.3168/jds.S0022-0302(02)74394-4.

Sheldon, I. M., D. E. Noakes, A. N. Rycroft, D. U. Pfeiffer, and H. Dobson. 2002. Influence of uterine bacterial contamination after parturition on ovarian dominant follicle selection and follicle growth and function in cattle. Reproduction 123:837-845. https:/ /doi.org/10.1530/rep.0.1230837.

Social Science Statistics. 2019. Easy Fisher Exact Test calculator. Accessed Nov. 15, 2019. https://www.socscistatistics.com/tests/ fisher/default2.aspx.

Thatcher, W. W., and C. J. Wilcox. 1973. Postpartum estrus as an indicator of reproductive status in the dairy cow. J. Dairy Sci. 56:608-610. https://doi.org/10.3168/jds.S0022-0302(73)85227-0.

VanRaden, P. M., A. H. Sanders, M. E. Tooker, R. H. Miller, H. D. Norman, M. T. Kuhn, and G. R. Wiggans. 2004. Development of a national genetic evaluation for cow fertility. J. Dairy Sci. 87:22852292. https://doi.org/10.3168/jds.S0022-0302(04)70049-1.

Verkerk, G. 2003. Pasture-based dairying: Challenges and rewards for New Zealand producers. Theriogenology 59:553-561. https://doi .org/10.1016/S0093-691X(02)01239-6.

Veronese, A., O. Marques, F. Penagaricano, R. S. Bisinotto, K. G. Pohler, T. R. Bilby, and R. C. Chebel. 2019. Genomic merit for reproductive traits. II: Physiological responses of Holstein heifers. J. Dairy Sci. 102:6639-6648. https://doi.org/10.3168/jds.2018-15245.

Williams, E. J., D. P. Fischer, D. E. Noakes, G. C. England, A. Rycroft, H. Dobson, and I. M. Sheldon. 2007. The relationship between uterine pathogen growth density and ovarian function in the postpartum dairy cow. Theriogenology 68:549-559. https://doi .org/10.1016/j.theriogenology.2007.04.056.

\section{ORCIDS}

S. Meier @ https://orcid.org/0000-0002-4386-7734

B. Kuhn-Sherlock @ ittps://orcid.org/0000-0002-1890-0301

P. A. Amer () https://orcid.org/0000-0002-6428-7165

J. R. Roche $\odot$ https://orcid.org/0000-0002-4165-9253

C. R. Burke @ https://orcid.org/0000-0003-3868-8675 